\title{
Greenhouse gas emission estimate in sugarcane irrigation in Brazil: is it possible to reduce it, and still increase crop yield?
}

\author{
Nilceu Piffer Cardozo a, ${ }^{\text {, }}$, Ricardo de Oliveira Bordonal ${ }^{\text {b }}$, Newton La Scala Jr. ${ }^{b}$ \\ a Sugarcane Research Center, Piracicaba, SP, Brazil \\ ${ }^{\mathrm{b}}$ Department of Exact Sciences, College of Agricultural and Veterinarian Sciences, São Paulo State University (FCAV/UNESP), \\ Via de Acesso Prof. Paulo Donato Castellane s/n, Jaboticabal, SP 14884-900, Brazil
}

\section{A R T I C L E I N F O}

\section{Article history:}

Received 10 April 2015

Received in revised form

5 September 2015

Accepted 11 September 2015

Available online 21 September 2015

\section{Keywords:}

Saccharum officinarum

Carbon footprint

Modeling

Sustainable production

Greenhouse gas inventory

Climate change

\begin{abstract}
A B S T R A C T
Irrigation increases sugarcane yield, especially in areas under restricted rainfall conditions. However, few studies have been carried out on the environmental impacts of this activity, mainly regarding greenhouse gas (GHG) emissions. Therefore, the aim of this study was to estimate the environmental impacts of sugarcane irrigation, contemplating GHG emissions at different production scenarios. For that, biomass production was simulated under rainfed conditions and different irrigation systems, comparing six Brazilian regions (Ribeirão Preto - SP; Araçatuba - SP; Paracatu - MG; Itumbiara - GO; Paranaíba MS; and Petrolina - PE). After gathered, GHG emission estimates of each scenario were confronted with sugarcane production data. The results were expressed in "carbon $(\mathrm{C})$ footprint" $\left(\mathrm{kg} \mathrm{CO}_{2} \mathrm{eq} \mathrm{t}^{-1}\right)$. For all evaluated regions, irrigation intensifies and encumbers environmentally the agricultural practices by increasing GHG emissions ( $\left.7447.0 \mathrm{~kg} \mathrm{CO}_{2} \mathrm{eq} \mathrm{ha} \mathrm{ha}^{-1} \mathrm{yr}^{-1}\right)$ compared with rainfed condition $\left(\sim 2154.6 \mathrm{~kg} \mathrm{CO}_{2}\right.$ eq ha $\left.{ }^{-1} \mathrm{yr}^{-1}\right)$. Irrigation systems require a large amount of electric power, diesel and other inputs such as synthetic nitrogen fertilizers. Surprisingly, this situation can change substantially if $C$ footprint is considered. We observed that irrigated areas had a decrease $C$ footprint of up to $59 \%$ (33.0 kg CO 2 eq t ${ }^{-1}$ ) against rainfed ones, as observed in Petrolina scenario. In other regions, $\mathrm{C}$ footprint reductions ranged from $23 \%\left(7.1 \mathrm{~kg} \mathrm{CO}_{2} \mathrm{eq} \mathrm{t}^{-1}\right)$ in Ribeirão Preto to $37 \%\left(13.9 \mathrm{~kg} \mathrm{CO}_{2} \mathrm{eq} \mathrm{t}^{-1}\right)$ in Paracatu. Thus, irrigated agriculture impact could be explored in terms of $C$ footprint, which depends on regional biomass production as well as irrigation system efficiency towards a better water use.
\end{abstract}

() 2015 Elsevier Ltd. All rights reserved.

\section{Introduction}

Human activities have rapidly increased worldwide, as consequence they brought environmental changes that resulted in short and medium-term influences on global agriculture and economy. Concerns about energy shortage, greenhouse gas (GHG) reductions and new income sources for farmers may explain why energy policies of many countries have considered biofuels as relevant alternative to fossil fuels (Demirbas, 2008; Tammisola, 2010).

Renewable energy use is one of the most efficient ways to reach sustainable development. Most of the "new renewable energy sources" are still undergoing large-scale commercial development; however, some technologies have already been established such as

\footnotetext{
* Corresponding author. Tel.: +55 16 32092624; fax: +55 1632024275.

E-mail addresses: nilceu.cardozo@terra.com.br (N.P. Cardozo), rbordonal@ yahoo.com.br (R.O. Bordonal), lascala@fcav.unesp.br (N. La Scala).
}

Brazilian sugarcane ethanol (Goldemberg, 2007). Brazil is the largest worldwide producer of sugarcane, with an output of 715 million tons within 9.6 million hectares, being 55\% of that in São Paulo State (FNP, 2013). About 18\% of the total consumed energy in Brazil comes from sugarcane ethanol, which makes it the second source of energy in the country (Jank, 2010). Nevertheless, recent crop's expansion has not considered the production potential based on weather conditions and management practices (Monteiro and Sentelhas, 2014).

Brazilian sugarcane production has grown substantially in recent years toward new agricultural areas, such as cerrado areas under critical climatic conditions, to satisfy the global demand for biofuels (Endres et al., 2010; Vianna and Sentelhas, 2015; Scarpare et al., 2015a). This growth, coupled with inter-annual climate variability and increasing mechanization, brought consequences to sugarcane growth patterns, maturation and crop yield in Brazil (Cardozo and Sentelhas, 2013; Scarpare et al., 2015b). 
Irrigation has emerged as one of the main alternatives to enhance sugarcane yield, especially in regions with limited water availability (Scarpare et al., 2015a). Several researchers have already shown the technical feasibility of irrigation with this crop resulting in considerable yield increases (normally above $140 \mathrm{t} \mathrm{ha}^{-1}$ ). These researches have focused on economic efficiency, longer plant longevity (more than 10 harvests) and steady yield (reducing yield variation between harvests) (Freitas et al., 2009).

Despite to the higher yield gains, the intensification of agricultural practices results in higher consumption of energy and fertilizers, thereby increasing GHG emissions from irrigation systems (Mosier et al., 1998; Linn and Doran, 1984). Maraseni and Cockfield (2012) concluded that irrigated crops emit 700\% more GHG because of a high consumption of fuel (diesel) and power for irrigation system as well as because of a large use of agricultural inputs like fertilizers and other agrochemicals.

According to Maraseni and Cockfield (2012), irrigation was responsible for a huge leap in agricultural yield in Australia. Over the last 30 years, Australian agricultural production has increased $2.8 \%$ per year, a rate higher than that achieved by country's economy. This increase is related to intensification of domestic farming allied to both irrigation and mechanization of agriculture (AGO, 2006). Nonetheless, Maraseni and Cockfield (2012) reported potential environmental impacts brought by such agricultural intensification (including irrigation). These authors also stated that larger energy and fertilizer consumptions could have promoted an increase in GHG emissions, which has not been taken into account so far.

Irrigated agriculture requires heavy machinery (i.e., higher diesel consumption) for soil tillage besides more power for water pumping. Additionally, irrigated systems in general demand more agrochemicals, primarily nitrogen $(\mathrm{N})$ fertilizers (Maraseni and Cockfield, 2012). It is estimated that more than half of that $\mathrm{N}$ is leached out of soil profile or released into the atmosphere as nitrous oxide $\left(\mathrm{N}_{2} \mathrm{O}\right)$ (Vergé et al., 2007). This $\mathrm{N}$ form has 298 times more global warming potential than carbon dioxide $\left(\mathrm{CO}_{2}\right)$ (IPCC, 2007). In conclusion, the more the farmers attempt to enhance production levels through irrigation, the larger the contribution of fertilizers to GHG emissions.

Evaluating some winter crops (barley, chickpeas, and common and durum wheat) under irrigation, Maraseni and Cockfield (2012) concluded that these irrigated crops emit more amount of GHG into the atmosphere, especially because of prior soil tillage, higher diesel consumption during harvest, irrigation system power consumption and larger use of inputs such as fertilizers and other agrochemicals. However, when comparing rainfed and irrigated system, the first one emits only about $159 \mathrm{~kg} \mathrm{CO}_{2} \mathrm{eq} \mathrm{ha}{ }^{-1}$, while the second one is in charge of around $4170 \mathrm{~kg} \mathrm{CO}_{2} \mathrm{eq} \mathrm{ha}{ }^{-1}$; therefore, it requires increasing amounts of $\mathrm{N}$ fertilizers, whose emission factor is higher than other GHG sources. Furthermore, irrigated system generates an extra emission of $1974 \mathrm{~kg} \mathrm{CO}_{2} \mathrm{eq} \mathrm{ha}{ }^{-1}$, arising from water withdrawal and transportation and may vary with the system. Overall, producing one kilogram of grain (on average) under irrigations demands twice the GHG emission level compared to rainfed production.

Even though agriculture contributes significantly to total anthropogenic GHG emissions, the sector has several strategies to mitigate those (Smith et al., 2007). For this purpose, detailed inventories of emission sources should be conducted to establish further feasible strategies in line with economic interests (Nguyen et al., 2010). The $\mathrm{CO}_{2}$ flux between atmosphere and ecosystem is under natural conditions and is controlled by absorption via plant photosynthesis and emissions through respiration, decomposition and soil organic matter combustion.

The aim of this study was to estimate the environmental impacts of GHG emissions from irrigated sugarcane, through simulations in six producing-regions of Brazil. For that, crop yield was simulated under rainfed condition and different irrigation systems. The challenge was to assess implications of yield increase on GHG emissions and carbon (C) footprint over the different production scenarios. Therefore, our hypothesis is that the production enhancement by means of irrigation could result in increased sugarcane yield, thereby reducing the $C$ footprint of sugarcane production.

\section{Materials and methods}

\subsection{Evaluated locations}

Soil and weather conditions of six of the most important sugarcane-producing regions in Brazil were considered to perform the current study. Fig. 1 shows these studied regions, which are: 1) Ribeirão Preto - SP; 2) Araçatuba - SP; 3) Paracatu - MG; 4) Itumbiara - GO; 5) Paranaíba - MS; and 6) Petrolina - PE.

\subsection{Local soil and weather data}

Daily data of rainfall $(\mathrm{mm})$, air temperature $\left({ }^{\circ} \mathrm{C}\right)$ and photoperiod $(h)$ of a 32-year period (1982-2013) were obtained from local weather stations. The annual average values of these regions for the period between 1983 and 2013 are shown in Table 1. The data were provided by public agencies such as Instituto Nacional de Meteorologia (INMET), Escola Superior de Agricultura Luiz de Queiroz (ESALQ-USP), Universidade Estadual Paulista (UNESP) and Instituto Agronômico de Campinas (IAC). Table 2 shows the most representative soil types of each region, as well as their available water capacity (AWC) and sugarcane production environments.

\subsection{Simulation of harvests and planting dates}

Simulations comprised a period of 32 years (1982-2013), contemplating thus a wide range of climatic conditions. We agreed that plantings would be performed in April and harvests from the middle to the end of the season (September), when plants undergo water deficit stress (higher $\mathrm{kc}$ ) and adverse weather conditions (Cardozo et al., 2014). Simulation results were expressed on average yield per year $\left(\mathrm{t} \mathrm{ha}^{-1} \mathrm{yr}^{-1}\right)$, which varied with region and irrigation system (Table 3 ).

\subsection{Simulation of potential crop yield}

The Agro-ecological Zoning model (AEZ) proposed by Doorenbos and Kassam (1979) was used to calculate potential sugarcane yield. Several other authors have already used this model for sugarcane, such as Monteiro and Sentelhas (2014) and Oliveira et al. (2012). The weather input variables used by the model were extraterrestrial solar radiation $\left(\mathrm{MJ} \mathrm{m} \mathrm{m}^{-2}\right.$ day $\left.^{-1}\right)$, photoperiod $\left(\mathrm{h} \mathrm{day}^{-1}\right)$, sunlight $\left(\mathrm{h} \mathrm{dia}^{-1}\right)$ and air temperature $\left({ }^{\circ} \mathrm{C}\right)$, which were used to calculate the potential yield, as shown in equation (1):

$P Y=\sum_{i=1}^{m}\left(G P Y p_{i} \times C_{l a i} \times C_{r} \times C_{h} \times C_{s m}\right)$

wherein: $P Y=$ dry matter $(\mathrm{DM})$ potential yield in $\mathrm{t} D M \mathrm{ha}^{-1}$; $m=$ time interval between simulations (10 days); GPYpi = standard gross potential yield of dry matter in $\mathrm{t} \mathrm{DM} \mathrm{ha}^{-1} \mathrm{day}^{-1}$; Clai = leaf area index correction factor; $\mathrm{Cr}=$ crop respiration correction factor; $\mathrm{Ch}=$ harvest index (stems); and Csm = stem moisture coefficient. All correction coefficients are dimensionless. 


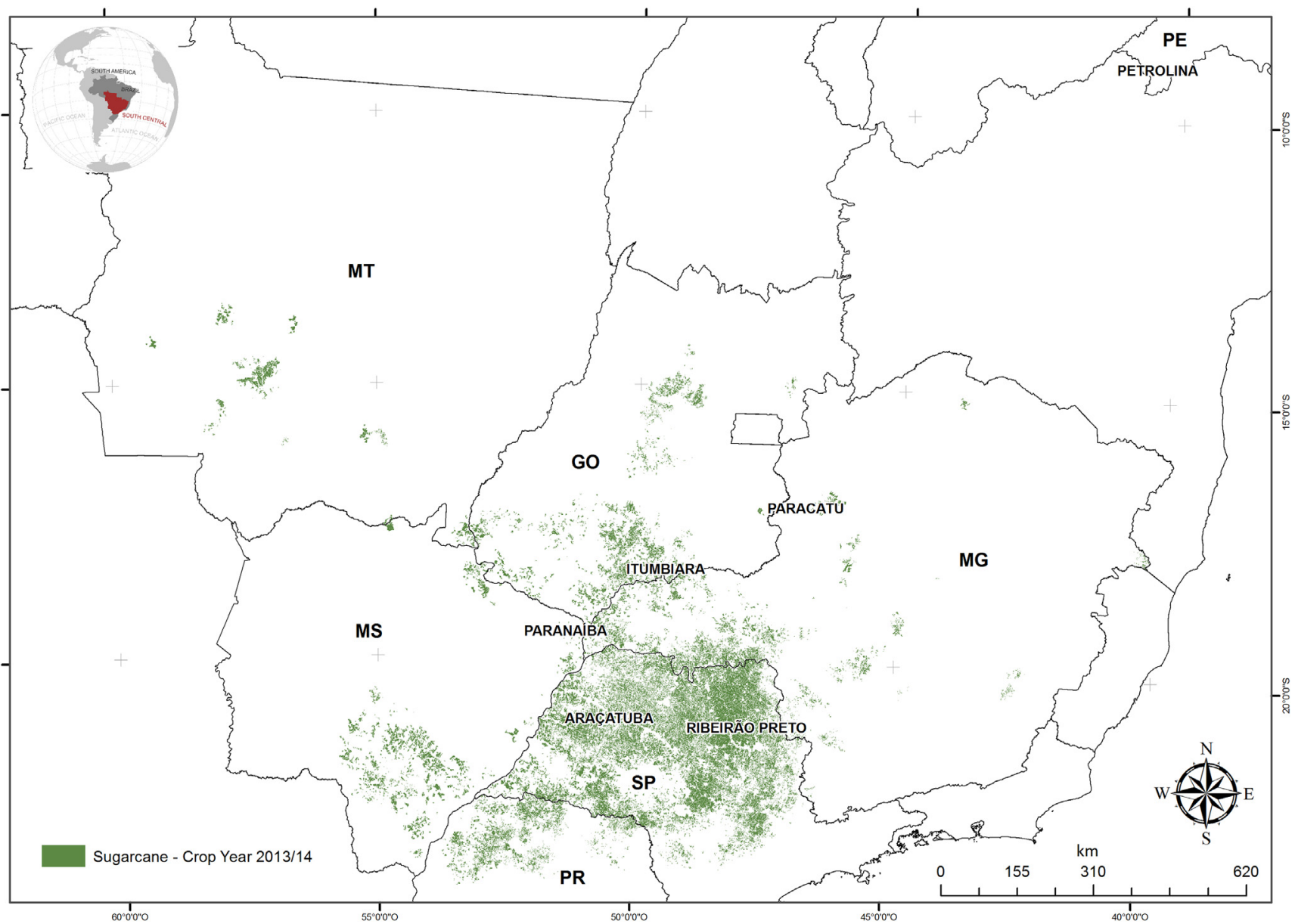

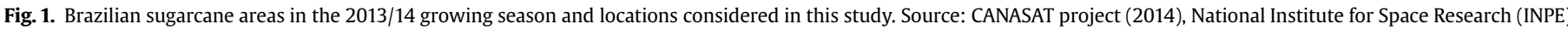
- http://www.dsr.inpe.br/laf/canasat.

Table 1

Mean weather conditions (1983-2013) of each evaluated region.

\begin{tabular}{|c|c|c|c|c|c|c|}
\hline \multirow[t]{2}{*}{ Region } & Rainfall & $\mathrm{T}_{\max }$ & $\mathrm{T}_{\min }$ & $\mathrm{T}_{\text {ave }}$ & \multirow{2}{*}{ 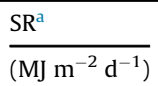 } & \multirow{2}{*}{$\frac{\text { Sunlight }}{\left(\mathrm{h} \mathrm{d}^{-1}\right)}$} \\
\hline & $\left(\mathrm{mm}\right.$ year $\left.^{-1}\right)$ & $\left({ }^{\circ} \mathrm{C}\right)$ & & & & \\
\hline Araçatuba & 1264.5 & 31.3 & 7.9 & 24.7 & 20.2 & 7.4 \\
\hline Ribeirão Preto & 1456.7 & 29.3 & 8.4 & 23.0 & 19.1 & 7.1 \\
\hline Paranaíba & 1461.9 & 30.9 & 6.0 & 24.1 & 20.9 & 7.5 \\
\hline Itumbiara & 1501.8 & 30.9 & 9.7 & 24.5 & 21.2 & 7.6 \\
\hline Paracatu & 1418.8 & 31.2 & 8.2 & 25.9 & 22.1 & 8.0 \\
\hline Petrolina & 506.4 & 32.2 & 17.6 & 27.1 & 23.2 & 8.9 \\
\hline
\end{tabular}

a SR: sun radiation.

The calculation of GPYp considered both gross potential yields in clean sky days (GPYclean) and in cloudy ones (GPYcloudy), once available energy for photosynthesis varies each day (Oliveira et al., 2012; Monteiro and Sentelhas, 2014). Additionally, GPYclean,
GPYcloudy and all other coefficients were exploited as seen in Doorenbos and Kassam (1979) and Oliveira et al. (2012). GPYp was also estimated in function of Clai data, as shown in equation (2) (Doorenbos and Kassam, 1979):

$$
C_{\text {lai }}=0.0093+0.185 \times L A I_{\max }-0.0175 \times L A I_{\max }^{2}
$$$$
\left(L A I_{\max } \geq 5 ; C_{L A I}=0.5\right)
$$

wherein: Clai = leaf area index correction factor; $L A I_{\max }=$ maximum leaf area index for the decade. Changes on the leaf area index ( $L A I)$ for cane-plant and ratoon was differentiated, following standards proposed by Doorenbos and Kassam (1979) and Monteiro and Sentelhas (2014) (Table 4).

GPYp bore the brunt of crop maintenance respiration $(\mathrm{Cr})$, which varied with average air temperature $(\mathrm{Tm})$, being 0.5 when $\mathrm{Tm}$ is higher or equals to $20{ }^{\circ} \mathrm{C}$; 0.6 for $\mathrm{Tm}$ at $20{ }^{\circ} \mathrm{C}$ (Doorenbos and

Table 2

Representative soil type, production environment, available water capacity in soil (AWC, in mm) and annual rainfall of each evaluated region.

\begin{tabular}{|c|c|c|c|}
\hline Region & Soil type & Production environment & $\mathrm{AWC}(\mathrm{mm})$ \\
\hline Araçatuba & Dystrophic Oxisol medium texture & $\mathrm{D}$ & 60 \\
\hline Ribeirão Preto & Dystroferric Oxisol & $\mathrm{B}$ & 100 \\
\hline Paranaíba & Dystrophic Oxisol medium texture & $\mathrm{D}$ & 60 \\
\hline Paracatu & Acric Oxisol clayey texture & $\mathrm{C}$ & 80 \\
\hline Itumbiara & Acri-ferric Oxisol clayey texture & $\mathrm{C}$ & 80 \\
\hline Petrolina & Dystrophic Yellow Ultisol sandy/medium texture & $\mathrm{C}$ & 80 \\
\hline
\end{tabular}

Adapted by Cardozo (2013). 
Table 3

Ratoon longevity (years/cycle) for each evaluated region in accordance with used irrigation systems.

\begin{tabular}{lllll}
\hline \multirow{2}{*}{ Region } & \multicolumn{2}{l}{ Irrigation system } & \\
\cline { 2 - 5 } & Rainfed & Self-propelled & Fixed pivot & Drip \\
\hline Araçatuba & 5 & 6 & 8 & 10 \\
Ribeirão Preto & 6 & 6 & 8 & 10 \\
Paranaíba & 4 & 5 & 8 & 10 \\
Itumbiara & 4 & 5 & 8 & 10 \\
Paracatu & 4 & 5 & 8 & 10 \\
Petrolina & 3 & 4 & 8 & 10 \\
\hline
\end{tabular}

Adapted by Cardozo (2013).

Kassam, 1979). The harvest index (Ch) was taken as $80 \%$ of total plant dry mass, and stem moisture coefficient (Csh) was calculated by equation (3) (Doorenbos and Kassam, 1979):

$C_{s h}=[1-0.001 \times H(\%)]^{-1}$

wherein: $H(\%)$ represents stem moisture in percentage (80\%).

\subsection{Estimation of real yield}

Estimations of sugarcane real yield $(R Y)$ of each region for rainfed condition and irrigated systems were performed according to Doorenbos and Kassam (1979) as in equation (4). These authors reported a relation between potential yield $\left(1-\mathrm{RY}_{\mathrm{df}} / \mathrm{PY}\right)$ drops and water deficit stress to which crop is subjected ( 1 - ETc/ETa), by means of a yield response factor (ky) of each phenological stage (Table 4).

$R Y_{d f}=\sum_{i=1}^{m} P Y \times\left[1-k y \times\left(1-\frac{E T a}{E T c}\right)\right]$

wherein: $R Y_{d f}=$ real yield of sugarcane under rainfed condition $\left(\mathrm{t} \mathrm{ha}^{-1}\right) ; i$ values $=$ decades within the cycle that varied from up to an $m$ value; $k y=$ yield response factor of each phenological stage; $E T a=$ actual evapotranspiration $(\mathrm{mm}) ;$ ETc $=$ crop evapotranspiration $(\mathrm{mm})$.

The ETa was estimated using the crop sequential water balance method developed by Thornthwaite and Mather (1955) simulated to a 32-year series (1982-2013). In the case of ETc, we used the sum of the reference evapotranspiration (ETo) and crop coefficient $(k c)$ of each phenological stage (Table 4). For that, ETo was determined by Thornthwaite's original method (Thornthwaite, 1948) adjusted by Camargo et al. (1999), in which average air temperature is replaced with effective one (equation (5)):

Tef $=0.36 \times[(3 \times$ Tmax $)-$ Tmin $]$

Table 4

Phenological phases, leaf area index (LAI), crop coefficient $(\mathrm{kc})$ and yield response factor (ky) of for cane-plant and ratoon.

\begin{tabular}{|c|c|c|c|c|c|c|}
\hline \multirow[t]{2}{*}{ Phenological phase } & \multicolumn{2}{|c|}{$\begin{array}{l}\text { Planting (18 } \\
\text { months) }\end{array}$} & \multicolumn{2}{|c|}{ Ratoon (12 months) } & \multirow[t]{2}{*}{ kc } & \multirow[t]{2}{*}{ ky } \\
\hline & LAI & Length (days) & LAI & Length (days) & & \\
\hline $25 \%$ full canopy & 2.5 & 40 & 2.0 & 30 & 0.5 & 0.8 \\
\hline $25-50 \%$ full canopy & 3.0 & 40 & 2.5 & 30 & 0.8 & 0.8 \\
\hline 50-75\% full canopy & 4.5 & 30 & 3.0 & 15 & 1.0 & 0.5 \\
\hline $75-100 \%$ full canopy & 5.0 & 50 & 3.5 & 50 & 1.1 & 0.5 \\
\hline $100 \%$ full canopy & 6.0 & 300 & 4.0 & 180 & 1.2 & 0.5 \\
\hline Senescence & 5.0 & 50 & 3.5 & 30 & 1.0 & 0.5 \\
\hline Ripening & 4.5 & 30 & 3.0 & 30 & 0.7 & 1.0 \\
\hline
\end{tabular}

Adapted by Cardozo (2013). wherein: $T e f=$ effective temperature; $T$ max $=$ maximum temperature; $\operatorname{Tmin}=$ minimum temperature, all in ${ }^{\circ} \mathrm{C}$.

\subsection{Estimation of sugarcane yield under irrigation}

Yield estimations of sugarcane under irrigation were made considering ETc estimated at ten-day scale for 32 crop seasons. We therefore established the following irrigation water replenishments: (i) $20 \%$ of ETc (saving irrigation), (ii) $70 \%$ of ETc (irrigation under water deficiency), (iii) $100 \%$ of ETc (potential yield). Each scenario had its water requirement estimated by the product of irrigation depths applied (20\%, $70 \%$ and $100 \%$ of ETc) and water distribution effectiveness of the irrigation system (Table 5).

\subsection{GHG emissions inventory}

Emissions calculations evaluated in the following production scenarios: C0 - traditional production under rainfed condition, C1 - irrigated production and saving irrigation (20\% of ETc) through a self-propelled irrigation system (diesel system); C2 - irrigated production and saving irrigation (20\% of ETc) using a self-propelled irrigation system (electrical system); C3 - irrigated production under water deficiency (70\% of ETc) through a fixed pivot (electrical system); 44 - irrigated production under water deficiency ( $70 \%$ of ETc) through drip irrigation (electrical system); C5 - irrigated production under full-scale irrigation (100\% of ETc) in a hypothetical system that has $100 \%$ application effectiveness (electrical system).

Soil tillage, planting, harvest and other crop management practices were assumed the same regardless of the evaluated scenario. Still, a few differences among the scenarios may come from fertilizer dosage and diesel consumption for cutting, transfer and transportation activities that are specific for each irrigation system and water depth. Moreover, the power demand (diesel or electrical) for irrigation can vary with water depth.

GHG emissions estimates were based on methodology proposed by the Intergovernmental Panel on Climate Change (IPCC, 2006), as performed by De Figueiredo and La Scala Jr (2011) and Bordonal et al. (2012) in sugarcane. Such estimates measure: a) $\mathrm{N}_{2} \mathrm{O}$ emissions from synthetic $\mathrm{N}$ fertilizers including during manufacturing and distribution (Macedo et al., 2008); b) produced organic compounds (vinasse and filter cake) as well as crop straw on soil surface (De Figueiredo and La Scala Jr, 2011); c) lime application and production; d) pesticide applications; e) diesel consumption of the main agricultural operations, including transport to the mill; f) irrigation system powered by diesel or electrical power.

Consumptions of inputs and diesel per hectare a year in mechanized unburned harvests were employed as input data, such as benchmarked by De Figueiredo and La Scala Jr (2011) and Bordonal et al. (2012). Each gas emission was converted into global warming potential (GWP) and expressed in $\mathrm{kg} \mathrm{CO}_{2} \mathrm{eq} \mathrm{ha} \mathrm{hr}^{-1} \mathrm{yr}^{-1}\left(\mathrm{CO}_{2}\right.$ equivalent) at a 100-year time horizon, being 1 for $\mathrm{CO}_{2}, 25$ for $\mathrm{CH}_{4}$ and 298 for $\mathrm{N}_{2} \mathrm{O}$ (IPCC, 2007).

Table 5

Average consumption of diesel $\left(\mathrm{L} \mathrm{mm}^{-1} \mathrm{ha}^{-1}\right)$, electric power $\left(\mathrm{kWh} \mathrm{mm}^{-1} \mathrm{ha}^{-1}\right)$ and water application efficiency (\%) according to the adopted irrigation system.

\begin{tabular}{lcll}
\hline & Self-propelled & Fixed pivot & Drip \\
\hline Diesel $\left(\mathrm{L} \mathrm{mm}^{-1} \mathrm{ha}^{-1}\right)$ & 2.5 & - & - \\
Electric power $\left(\mathrm{kWh} \mathrm{mm}^{-1} \mathrm{ha}^{-1}\right)$ & 13.5 & 5.0 & 5.0 \\
Application efficiency (\%) & $65 \%$ & $85 \%$ & $95 \%$ \\
\hline
\end{tabular}

Source: Adapted from Marouelli and Silva (1998) and Cardozo (2013). 


\subsection{1. $\mathrm{N}_{2} \mathrm{O}$ direct and indirect emissions}

The fraction of all $\mathrm{N}$ added from synthetic fertilizers, $\mathrm{N}$-mass in crop residues and organic compounds (such as vinasse and filter cake) were established as emission sources according to IPCC (2006) guidelines. Therefore, we adopted an emission factor (EF) of $1 \%$ per amount of available $\mathrm{N}$ in soil of any source. Indirect emissions had the same EF, and the fraction of volatilized N was $10 \%$ for synthetic fertilizers and $20 \%$ for organic compounds. However, for indirect emissions from leaching and runoff, the EF was $0.75 \%$, and the leaching fraction was 30\% (IPCC, 2006).

2.7.1.1. Synthetic $N$ fertilizer. Crops were fertilized with $40 \mathrm{~kg} \mathrm{~N} \mathrm{ha}^{-1}$ ammonium nitrate. According to Trivelin and Vitti (2005), it is recommended an application dose of $130 \mathrm{~kg} \mathrm{~N} \mathrm{ha}^{-1} \mathrm{yr}^{-1}$ to reach an expected yield of $100 \mathrm{t} \mathrm{ha}^{-1} \mathrm{yr}^{-1}$, which is usually increased in $30 \%$ because of straw presence on soil surface. Fertilizations were based on target yields, since the highest values are expected for irrigated sugarcane (Spironello et al., 1997), besides of being corrected by a factor of mechanized harvest as previously mentioned (Table 6).

Even though IPCC has set a standard $\mathrm{N}_{2} \mathrm{O}$ EF at $1.325 \% \mathrm{~N}_{2} \mathrm{O}-\mathrm{N}$ per $\mathrm{kg}$ of applied $\mathrm{N}$, we encountered in literature an EF of $2.1 \%$ $\left(0.021 \mathrm{~kg} \mathrm{~N} \mathrm{~N}_{2} \mathrm{O}-\mathrm{N}\right.$ for $\left.100 \mathrm{~kg} \mathrm{~N}^{-1}\right)$ for irrigated plantations. This increased $\mathrm{N}_{2} \mathrm{O}$ EF of irrigated crops is related to soil pore-filling by water (>E40\%); since oxygen diffusion decreases promoting favorable conditions for denitrifying bacteria growth (Dalal et al., 2003).

After calculating and converting $\mathrm{N}_{2} \mathrm{O}-\mathrm{N}$ amount into $\mathrm{N}_{2} \mathrm{O}$ (being multiplied by 1.57), it was again converted into $\mathrm{CO}_{2}$ eq. In addition to that, emissions related to the production and transportation phases of synthetic $\mathrm{N}$ fertilizers were considered under $\mathrm{EF}$ of $3.97 \mathrm{~kg} \mathrm{CO}_{2} \mathrm{eq} \mathrm{kg} \mathrm{kg}^{-1}$ of $\mathrm{N}$ (Macedo et al., 2008).

2.7.1.2. Organic compounds. Emissions derived from organic compounds were based on the filter cake and vinasse applications. Vinasse $\mathrm{N}$ content was considered to be $0.368 \mathrm{~kg} \mathrm{~N} \mathrm{~m}^{-3}$, with a rate of application of $120 \mathrm{~m}^{3} \mathrm{ha}^{-1}$, resulting in an average input of $44.16 \mathrm{~kg} \mathrm{ha}^{-1} \mathrm{yr}^{-1}$ (De Figueiredo and La Scala Jr, 2011). We considered that nitrogen accounted for $1.4 \%$ at $25 \%$ dry matter filter cake, which was applied in the planting furrow at a dose of $30 \mathrm{tha}^{-1}$ during reform period. Such rate corresponds to an average content of $17.5 \mathrm{~kg} \mathrm{~N} \mathrm{ha}^{-1} \mathrm{yr}^{-1}$ throughout six years of cultivation (Bordonal et al., 2012).

2.7.1.3. $\mathrm{N}_{2} \mathrm{O}$ emissions from sugarcane harvest residues. The mechanical harvesting generates large amounts of crop residues on the soil surface ranging from 12.5 to $24.9 \mathrm{t} \mathrm{ha}^{-1}$ MS (Ronquim, 2007). De Figueiredo and La Scala Jr (2011) and Bordonal et al. (2012) claimed that only $20 \%$ of $\mathrm{N}$ in residues is mineralized and converted into $\mathrm{N}_{2} \mathrm{O}$ emissions for one-year period $\left(60 \mathrm{~kg} \mathrm{ha}^{-1}\right)$, i.e., the equivalent of $12 \mathrm{~kg} \mathrm{~N} \mathrm{ha}^{-1} \mathrm{yr}^{-1}$. In this study, we considered that the left residue represented $14 \%$ of the achieved yield (Bordonal et al., 2012); therefore, this content varied with the assessed scenario and location.

Table 6

Nitrogen fertilization ( $\mathrm{kg} \mathrm{N} \mathrm{ha}^{-1}$ ) according to expected yield and correction in accordance with mechanized harvest.

\begin{tabular}{lcc}
\hline Expected yield & a Bulletin 100 & Correction due to mechanized harvest \\
\hline$<60$ & 60 & 80 \\
$60-80$ & 80 & 105 \\
$80-100$ & 100 & 130 \\
$>100$ & 120 & 160 \\
\hline
\end{tabular}

a Bulletin published with technical information on agriculture by Instituto Agronomico de Campinas (IAC). Source: Spironello et al. (1997).

\subsection{2. $\mathrm{CO}_{2}$ emissions from liming}

Liming was accounted at a dose of 2 tons $\mathrm{ha}^{-1}$ using dolomitic limestone in reform period (De Figueiredo and La Scala Jr, 2011). The EF was regarded as being 0.13 tons of $C$ per ton of lime applied (IPCC, 2006). In addition, we also considered the emissions related to limestone production stage, estimating an amount of $0.01 \mathrm{~kg}$ $\mathrm{CO}_{2}$ eq per kilogram of produced limestone (Macedo et al., 2008).

\subsubsection{Emissions from pesticide applications}

As in previous evaluations, emissions from production and transportation of insecticides and herbicides were accounted, and we took as basis the EFs suggested by Macedo et al. (2008), who indicated values of 29.0 and $25.0 \mathrm{~kg} \mathrm{CO}_{2} \mathrm{eq} \mathrm{kg} \mathrm{g}^{-1}$ for insecticides and herbicides, respectively. Both planting and ratoon treatment had insecticide applications of $0.16 \mathrm{~kg} \mathrm{ha}^{-1}$. For herbicides, doses of $2.2 \mathrm{~kg} \mathrm{ha}^{-1}$ were applied in planting and ratoon treatment, ending in an average of $1.8 \mathrm{~kg} \mathrm{ha}^{-1} \mathrm{yr}^{-1}$ during a 6-year crop cycle.

\subsubsection{Emissions from diesel}

Besides the diesel consumption during sugarcane cane-plant and ratoon (Table 7), harvest and transportation to the mill (Table 8), emissions from diesel extraction, processing and transportation were considered in our calculations (Macedo et al., 2004). Likewise, direct emissions of $\mathrm{CO}_{2}\left(74.100 \mathrm{~kg} \mathrm{CO} \mathrm{TJ}^{-1}\right), \mathrm{CH}_{4}$ $\left(4.15 \mathrm{~kg} \mathrm{CH}_{4} \mathrm{TJ}^{-1}\right)$ and $\mathrm{N}_{2} \mathrm{O}\left(28.6 \mathrm{~kg} \mathrm{~N}_{2} \mathrm{O} \mathrm{TJ}^{-1}\right)$ were imputed as designed by IPCC (2006). Diesel density was rated at $852 \mathrm{~g} \mathrm{~L}^{-1}$ with specific fuel consumption of $195 \mathrm{~g} \mathrm{kWh}^{-1}$ to determine the EF (De Figueiredo and La Scala Jr, 2011); thus, diesel consumption would have an $\mathrm{EF}$ of $2.671 \mathrm{~kg} \mathrm{CO}_{2} \mathrm{eq} \mathrm{L}^{-1}$. Moreover, diesel extraction, processing and distribution emissions were set at $0.581 \mathrm{~kg} \mathrm{CO}_{2} \mathrm{eq} \mathrm{L}{ }^{-1}$ (Macedo et al., 2008). This way, the diesel consumption generates a total emission of $3.252 \mathrm{~kg} \mathrm{CO}_{2} \mathrm{eq} \mathrm{L}^{-1}$.

Farming practices spend around $170.34 \mathrm{~L} \mathrm{ha}^{-1}$ within the first crop year (planting), being reduced to $17.69 \mathrm{~L} \mathrm{ha}^{-1}$ during ratoon treatment (Table 7). Diesel consumption from harvest (Table 8) was transformed into $\mathrm{L}$ per ton of stem, since total production varies with scenario yield and location.

\subsubsection{Emissions from irrigation systems}

Power consumption estimate (kW for electrical system or liters for diesel) ranged with irrigation method and represented the

\section{Table 7}

Overview of agricultural operations and diesel consumption $\left(\mathrm{L} \mathrm{ha}^{-1}\right)$ in plant and ratoon crops for all evaluated sugarcane scenarios.

\begin{tabular}{llr}
\hline Stage & Operation & L ha $^{-1}$ \\
\hline Soil preparation and planting & Ratoon chemical destruction & 1.60 \\
& Ratoon mechanical destruction & 11.09 \\
& Land systematizing & 30.00 \\
& Heavy plow & 21.23 \\
& Lime application & 3.73 \\
& Gypsum application & 3.73 \\
& Subsoiling & 26.00 \\
& Medium harrow & 21.23 \\
& Leveling harrow & 9.38 \\
& Filter cake application & 9.60 \\
& Mechanized planting & 25.00 \\
& Herbicide application & 1.60 \\
& Hilling-up & 6.15 \\
Total (1) & & 170.34 \\
Ratoon treatments & Fertilization & 7.08 \\
& Vinasse (transp. + application) & 7.41 \\
& Herbicide application & 1.60 \\
& Insecticide application & 1.60 \\
Total (2) & & 17.69 \\
Average annual consumption & & 188.03 \\
\hline
\end{tabular}

Obs.: Mechanized planting and conventional preparation. 
Table 8

Overview of agricultural operations and diesel consumption ( $\mathrm{L} \mathrm{ha}^{-1}$ ) related to sugarcane harvest and transportation to the mill.

\begin{tabular}{lll}
\hline Stage & Operation & $\mathrm{L} \mathrm{t}^{-1}$ \\
\hline Harvesting & Harvester & 0.93 \\
& Transfer & 0.27 \\
Total & Transportation & 1.03 \\
& & 2.22 \\
\hline
\end{tabular}

product of irrigation levels (20\%, $70 \%$ and $100 \%$ ), method effectiveness and average power consumption per millimeter of applied water (Table 5; equation (6)). The $\mathrm{CO}_{2}$ emissions per $\mathrm{kWh}$ were equal to monthly emissions from 2006 to 2012 (MCT, 2010), having a value of $0.0413 \mathrm{~kg} \mathrm{CO}_{2} \mathrm{kWh}^{-1}$. As diesel $\mathrm{EF}$, we used the same as for the agricultural machinery of $3.252 \mathrm{~kg} \mathrm{CO}_{2} \mathrm{eq} \mathrm{L}^{-1}$ (Macedo et al., 2008).

$P C=I D \times A E \times E C$

wherein: $P C=$ power consumption $(\mathrm{kW}) ; I D=$ irrigation depth $(\mathrm{mm}) ; A E=$ system application efficiency (\%) and $E C=$ energy consumption per millimeter of applied water $\left(\mathrm{kW} \mathrm{mm}^{-1}\right)$.

\section{Results}

\subsection{Sugarcane yield under rainfed condition and irrigated systems}

Table 9 shows the PY estimates for each evaluated region and scenario. PY ranged from $148.7 \mathrm{t} \mathrm{ha}^{-1}$ in Ribeirão Preto to $168.1 \mathrm{t} \mathrm{ha}^{-1}$ in Petrolina. The other regions had intermediate values (Araçatuba - $150.2 \mathrm{t} \mathrm{ha}^{-1}$, Paranaíba $-151.1 \mathrm{t} \mathrm{ha}^{-1}$, Itumbiara 154.0 t ha ${ }^{-1}$ and Paracatu - $161.1 \mathrm{t} \mathrm{ha}^{-1}$ ).

However, when analyzing $\mathrm{RY}_{\mathrm{d}}$ under rainfed condition, this background changes completely. The largest $\mathrm{RY}_{\mathrm{d}}$ value was achieved in Ribeirão Preto (87.9 $\left.\mathrm{t} \mathrm{ha}^{-1}\right)$ and followed by Itumbiara (71.8 $\left.\mathrm{t} \mathrm{ha}^{-1}\right)$, Araçatuba $\left(71.0 \mathrm{t} \mathrm{ha}^{-1}\right)$, Paranaíba $\left(67.6 \mathrm{t} \mathrm{ha}^{-1}\right)$, Paracatu (58.7 $\mathrm{t} \mathrm{ha}^{-1}$ ) and the lowest one in Petrolina $\left(37.8 \mathrm{t} \mathrm{ha}^{-1}\right)$. Such small yield hinders sugarcane farming under rainfed conditions; indeed, there is no crop cultivation without irrigation in this region.

Irrigation testing pointed to yield gains for all regions, even with regional climatic variations. Saving irrigation provided yields ranging from $72 \mathrm{t} \mathrm{ha}^{-1}$ in Petrolina to $92.6 \mathrm{t} \mathrm{ha}^{-1}$ in Ribeirão Preto that, even having the highest yield, it still had a slight gain. Nevertheless, when contrasting pivot and drip systems (70\% of ETc), Ribeirão Preto Ribeirão Preto was moved back to the last position in yield gain.

\subsection{Total annual emissions at each scenario}

Fig. 2 shows total GHG emissions ( $\mathrm{kg} \mathrm{CO}_{2} \mathrm{eq} \mathrm{ha} \mathrm{hr}^{-1} \mathrm{yr}^{-1}$ ) of irrigation systems. Ribeirão Preto, Araçatuba and Itumbiara showed the largest estimates under rainfed conditions (C0), with values near 3306; 2427 and $2001 \mathrm{~kg} \mathrm{CO}$ eq ha ${ }^{-1} \mathrm{yr}^{-1}$, respectively. Meanwhile, Paranaíba, Paracatu and Petrolina had the lowest values of 1969; 1951 and $1272 \mathrm{~kg} \mathrm{CO}_{2} \mathrm{eq} \mathrm{ha}{ }^{-1} \mathrm{yr}^{-1}$, respectively. This variation follows yield increase, because the more the crop yields, the more fertilizer and diesel are used in harvesting and transportation activities. Bordonal et al. (2012) found similar results, evaluating mechanized harvesting and observing an average yield of $81 \mathrm{t} \mathrm{ha}^{-1}$ in São Paulo state with emission values close to $2316 \mathrm{~kg} \mathrm{CO}_{2}$ eq ha ${ }^{-1} \mathrm{yr}^{-1}$.

Diesel-powered saving irrigation (C1) increased in 200\% total emissions. Once again, Ribeirão Preto, Araçatuba and Itumbiara had
Table 9

Sugarcane yield ( $\mathrm{t} \mathrm{ha}^{-1}$ ) under rainfed condition and irrigated systems in six producing-regions of Brazil.

\begin{tabular}{|c|c|c|c|c|c|}
\hline & Rainfed & Saving & Fixed pivot & Drip & Potential \\
\hline \multicolumn{6}{|l|}{ Araçatuba } \\
\hline Average & 71.0 & 85.3 & 105.4 & 110.1 & 150.2 \\
\hline Maximum & 86.5 & 96.5 & 119.2 & 124.7 & 162.3 \\
\hline Minimum & 48.1 & 66.7 & 94.4 & 98.5 & 138.1 \\
\hline Standard deviation & 15.9 & 13.3 & 5.9 & 6.2 & 5.4 \\
\hline V.C. $\%$ & $22.40 \%$ & $15.60 \%$ & $5.60 \%$ & $5.70 \%$ & $3.60 \%$ \\
\hline \multicolumn{6}{|l|}{ Ribeirão Preto } \\
\hline Average & 87.9 & 92.6 & 103.1 & 108.1 & 148.7 \\
\hline Maximum & 99.4 & 104.7 & 116.6 & 122.4 & 160.7 \\
\hline Minimum & 60 & 73.5 & 93 & 97.5 & 136.6 \\
\hline Standard deviation & 19.4 & 14.2 & 5.9 & 6.2 & 5.4 \\
\hline V.C. $\%$ & $22.10 \%$ & $15.30 \%$ & $5.70 \%$ & $5.80 \%$ & $3.60 \%$ \\
\hline \multicolumn{6}{|l|}{ Paranaíba } \\
\hline Average & 67.6 & 83.2 & 106.8 & 112.1 & 151.1 \\
\hline Maximum & 79.2 & 94.1 & 120.7 & 126.8 & 163.4 \\
\hline Minimum & 45.6 & 64.8 & 95.6 & 100.3 & 138.9 \\
\hline Standard deviation & 15.3 & 12.9 & 5.9 & 6.3 & 5.4 \\
\hline V.C. $\%$ & $22.60 \%$ & $15.50 \%$ & $5.60 \%$ & $5.60 \%$ & $3.60 \%$ \\
\hline \multicolumn{6}{|l|}{ Itumbiara } \\
\hline Average & 71.8 & 87.4 & 109.1 & 118.7 & 154 \\
\hline Maximum & 81.1 & 98.7 & 123.2 & 134.1 & 166.5 \\
\hline Minimum & 49.5 & 69.3 & 98.3 & 106.9 & 141.6 \\
\hline Standard deviation & 16.0 & 13.5 & 6.1 & 6.7 & 5.5 \\
\hline V.C. $\%$ & $22.20 \%$ & $15.50 \%$ & $5.60 \%$ & $5.70 \%$ & $3.60 \%$ \\
\hline \multicolumn{6}{|l|}{ Paracatu } \\
\hline Average & 58.7 & 84.3 & 115.4 & 123.6 & 161.1 \\
\hline Maximum & 73.6 & 95.3 & 130.6 & 139.9 & 174 \\
\hline Minimum & 39.8 & 65.8 & 103.3 & 110.6 & 148.2 \\
\hline Standard deviation & 12.9 & 13.0 & 6.5 & 7.0 & 5.7 \\
\hline V.C. $\%$ & $22.00 \%$ & $15.40 \%$ & $5.60 \%$ & $5.60 \%$ & $3.50 \%$ \\
\hline \multicolumn{6}{|l|}{ Petrolina } \\
\hline Average & 37.8 & 72 & 117.6 & 131.2 & 168.1 \\
\hline Maximum & 60.3 & 81.3 & 132.8 & 148.4 & 181.9 \\
\hline Minimum & 25.8 & 56.7 & 105.6 & 117.5 & 154.8 \\
\hline Standard deviation & 7.8 & 10.6 & 6.5 & 7.3 & 6.0 \\
\hline V.C. $\%$ & $20.70 \%$ & $14.70 \%$ & $5.50 \%$ & $5.60 \%$ & $3.60 \%$ \\
\hline
\end{tabular}

the lowest growth rates (128, 194 and 194\%), and Paranaíba, Paracatu and Petrolina the largest ones (209, 211 and 260\%). In terms of total emissions, Araçatuba became the largest emitter $(4706.1 \mathrm{~kg}$ $\mathrm{CO}_{2}$ eq $\left.\mathrm{ha}^{-1} \mathrm{yr}^{-1}\right)$, followed by Ribeirão Preto $(4216.9 \mathrm{~kg}$ $\mathrm{CO}_{2}$ eq ha ${ }^{-1} \mathrm{yr}^{-1}$ ), Paranaíba (4115.6 $\mathrm{kg} \mathrm{CO}_{2} \mathrm{eq} \mathrm{ha}{ }^{-1} \mathrm{yr}^{-1}$ ), Paracatu (4116.0 $\mathrm{kg} \mathrm{CO}_{2} \mathrm{eq} \mathrm{ha}{ }^{-1} \mathrm{yr}^{-1}$ ), Itumbiara (3877.7 kg CO $\mathrm{eq} \mathrm{ha}^{-1} \mathrm{yr}^{-1}$ ) and Petrolina (3312.1 $\mathrm{kg} \mathrm{CO}_{2} \mathrm{eq} \mathrm{ha} \mathrm{hr}^{-1} \mathrm{yr}^{-1}$ ). Local variations in irrigation demand may explain the wide-range increase, once irrigation demands diesel consumption. Furthermore, saving irrigation practice can considerably change the production overview in some regions. However, such changes bring major fertilizer and diesel consumptions for harvesting and transportation. Most noteworthy is the case of Petrolina, where the intense water stress led to the need for a $165 \mathrm{~mm} \mathrm{yr}^{-1}$ irrigation depth in saving irrigations, which could provide an yield change from $37.8 \mathrm{t} \mathrm{ha}^{-1}$ (rainfed) to $72.0 \mathrm{t} \mathrm{ha}^{-1}$ (under irrigation), promoting $90 \%$ yield gain.

By simply exchanging diesel with electric power (C2), there was an average reduction of $70 \%$ in emissions, against $\mathrm{C} 1$ scenario. In this case, Ribeirão Preto remains with higher emissions (3407.8 $\mathrm{kg} \mathrm{CO}_{2}$ eq ha ${ }^{-1} \mathrm{yr}^{-1}$ ), followed by Araçatuba $(3357.6 \mathrm{~kg}$ $\mathrm{CO}_{2}$ eq ha ${ }^{-1} \mathrm{yr}^{-1}$ ), Itumbiara (2847.6 kg CO $2 \mathrm{eq} \mathrm{ha}^{-1} \mathrm{yr}^{-1}$ ), Paranaíba $\left(2823.3 \mathrm{~kg} \mathrm{CO}_{2}\right.$ eq ha $\left.{ }^{-1} \mathrm{yr}^{-1}\right)$, Paracatu (2833.1 kg CO 2 eq ha ${ }^{-1} \mathrm{yr}^{-1}$ ) and Petrolina (2276.0 $\mathrm{kg} \mathrm{CO}_{2} \mathrm{eq} \mathrm{ha} \mathrm{hr}^{-1} \mathrm{yr}^{-1}$ ). The use of irrigation did not change the order of regions in terms of annual emissions; therefore, fertilizer and diesel use in harvest and transportation were the highest sources of GHG emission. Emission levels per kWh are very low in Brazil if compared with other countries where the main energy resources are coal and fossil fuel (Cerri et al., 2007), 


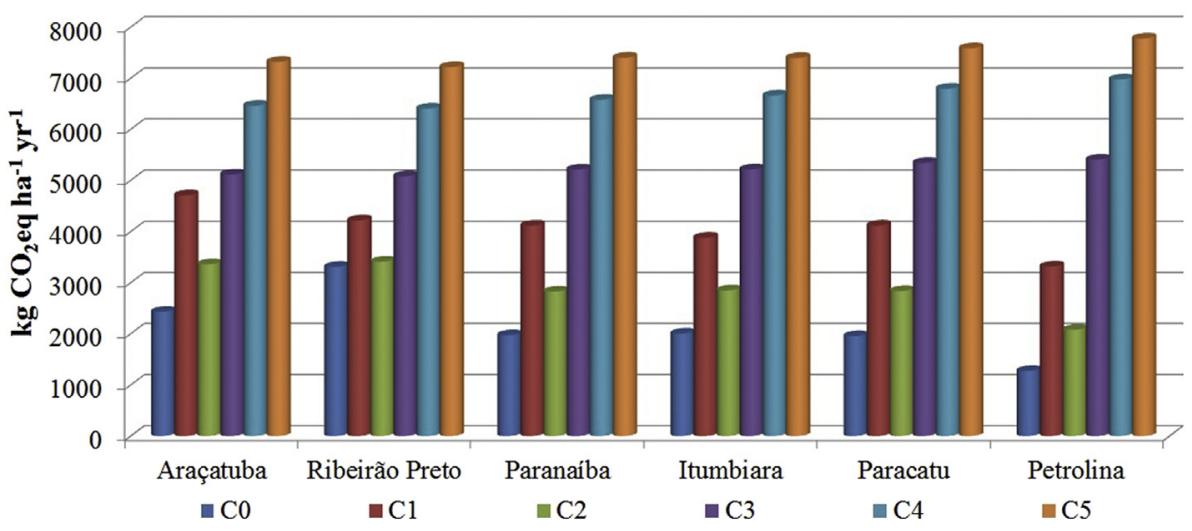

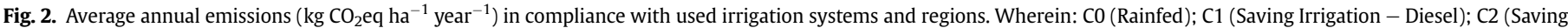
Irrigation - Electric power); C3 (Center Fixed Pivot Irrigation); C4 (Drip Irrigation); C5 (Hypothetical Irrigation).

since much of the domestic energy generation (75\%) comes from renewable resources, i.e., energy hydropower and biomass cogeneration (MME, 2015).

Center-pivot irrigation (C3) had 265\% higher emissions against rainfed. In this case, the highest emitters were Petrolina (5404.5 kg CO $\mathrm{keq} \mathrm{ha}^{-1} \mathrm{yr}^{-1}$ ) and Paracatu (5338.6 kg CO $2 \mathrm{eq}$ $\left.\mathrm{ha}^{-1} \mathrm{yr}^{-1}\right)$, followed by Itumbiara (5212.1 kg CO $\left.\mathrm{eq} \mathrm{ha}^{-1} \mathrm{yr}^{-1}\right)$, Paranaíba (5209.3 kg CO $2 \mathrm{eq} \mathrm{ha} \mathrm{hr}^{-1} \mathrm{yr}^{-1}$ ), Araçatuba (5111.4 kg $\mathrm{CO}_{2}$ eq ha ${ }^{-1} \mathrm{yr}^{-1}$ ) and Ribeirão Preto (5077.5 $\mathrm{kg} \mathrm{CO}_{2} \mathrm{eq} \mathrm{ha} \mathrm{hr}^{-1} \mathrm{yr}^{-1}$ ).

Drip irrigation (C4) and hypothetical system (C5) showed the same sequence of emitters as in C3. For these scenarios, average emissions raised in $337 \%$ and $377 \%$ for C4 and C5, respectively. In C4, the greatest emitters were Petrolina (6973.5 $\mathrm{kg} \mathrm{CO}_{2} \mathrm{eq} \mathrm{ha}{ }^{-1} \mathrm{yr}^{-1}$ ) and Paracatu (6790.7 $\mathrm{kg} \mathrm{CO}_{2} \mathrm{eq} \mathrm{ha}{ }^{-1} \mathrm{yr}^{-1}$ ), followed by Itumbiara (6673.1 $\mathrm{kg} \mathrm{CO} \mathrm{CO}_{2} \mathrm{ha}^{-1} \mathrm{yr}^{-1}$ ), Paranaíba $\left(6558.8 \mathrm{~kg} \quad \mathrm{CO}_{2} \mathrm{eq} \mathrm{ha}^{-1} \mathrm{yr}^{-1}\right)$, Araçatuba $(6458.5 \mathrm{~kg}$ $\mathrm{CO}_{2}$ eq ha ${ }^{-1} \mathrm{yr}^{-1}$ ) and Ribeirão Preto (6403.4 $\mathrm{kg} \mathrm{CO}_{2} \mathrm{eq} \mathrm{ha}{ }^{-1} \mathrm{yr}^{-1}$ ). Meanwhile, in $\mathrm{C} 5$, the greatest GHG emissions were observed in Petrolina (7775.0 kg CO $\mathrm{eq} \mathrm{ha} \mathrm{hr}^{-1}$ ), Paracatu $(7583.4 \mathrm{~kg}$

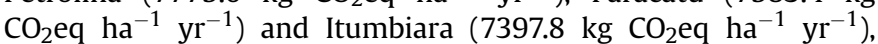
promptly followed by Paranaíba (7393.8 kg CO $2 \mathrm{eq} \mathrm{ha}{ }^{-1} \mathrm{yr}^{-1}$ ), Araçatuba (7316.8 kg CO $2 \mathrm{eq} \mathrm{ha} \mathrm{hr}^{-1}$ ) and Ribeirão Preto (7215.0 kg CO $\mathrm{keq} \mathrm{ha}^{-1} \mathrm{yr}^{-1}$ ).

\subsection{C footprint of the proposed systems}

Fig. 3 shows the values of $C$ footprint in each production scenario. In rainfed conditions, Ribeirão Preto had the smallest value of all studied regions ( $31.3 \mathrm{~kg} \mathrm{CO} \mathrm{Ce}_{2}$ per ton of produced sugarcane), what makes it the best scenario regarding $C$ footprint. Then, in sequence, Araçatuba $\left(34.2 \mathrm{~kg} \quad \mathrm{CO}_{2} \mathrm{eq} \mathrm{t}^{-1}\right)$, Itumbiara (34.8 $\mathrm{kg} \mathrm{CO}_{2} \mathrm{eq} \mathrm{t}^{-1}$ ), Paranaíba (36.4 kg CO $\mathrm{eq} \mathrm{t}^{-1}$ ) and Paracatu (37.4 $\mathrm{kg} \mathrm{CO}_{2} \mathrm{eq} \mathrm{t}^{-1}$ ) followed it. We also find, rather surprisingly, that Petrolina had the highest $\mathrm{C}$ footprint $\left(56.1 \mathrm{~kg} \mathrm{CO}_{2} \mathrm{eq} \mathrm{t}^{-1}\right)$, which is related to local lower yields and crop longevity in rainfed conditions.

All locations presented increasing $\mathrm{C}$ footprint in $\mathrm{C} 1$. Such result is tied up to diesel use that strongly increases emissions, but it is not offset by increased yield. On average, $C$ footprint was increased in $25 \%$, reaching a maximum rate of $36 \%$ in Paranaíba and minimum one of $2 \%$ in Petrolina. The increasing on total GHG emissions of $\mathrm{C} 1$ was largest in Petrolina, which is due to increased demand for irrigation water and, consequently, diesel consumption. However, the $\mathrm{C}$ footprint increase (2\%) resulted from saving irrigation effect on rainfed region yield, which showed an increase of $91 \%$ (34.2 t ha $^{-1}$; Table 9).

Fig. 4 shows the variation in $C$ footprint for scenarios under irrigation (C1 to C5) and rainfed condition (C0). As can be seen, C1 had a positive variation, while saving irrigation got the least efficiency; in other words, lower production with higher emissions. Conversely, C2, which is powered by electric power, showed a decrease in $\mathrm{C}$ footprint compared to $\mathrm{C} 0$. The values ranged from $30.7\left(\mathrm{~kg} \mathrm{CO}_{2}\right.$ eq t$\left.{ }^{-1}\right)$ in Ribeirão Preto and $36.1\left(\mathrm{~kg} \mathrm{CO}_{2}\right.$ eq t $\left.{ }^{-1}\right)$ in Petrolina. In this system, the mean reduction was $11 \%$ among all the sites evaluated (Fig. 4). Compared to $\mathrm{C} 1, \mathrm{C} 2$ had an average reduction of $36 \%\left(14.1 \mathrm{~kg} \mathrm{CO}_{2}\right.$ eq t $\left.\mathrm{t}^{-1}\right)$.

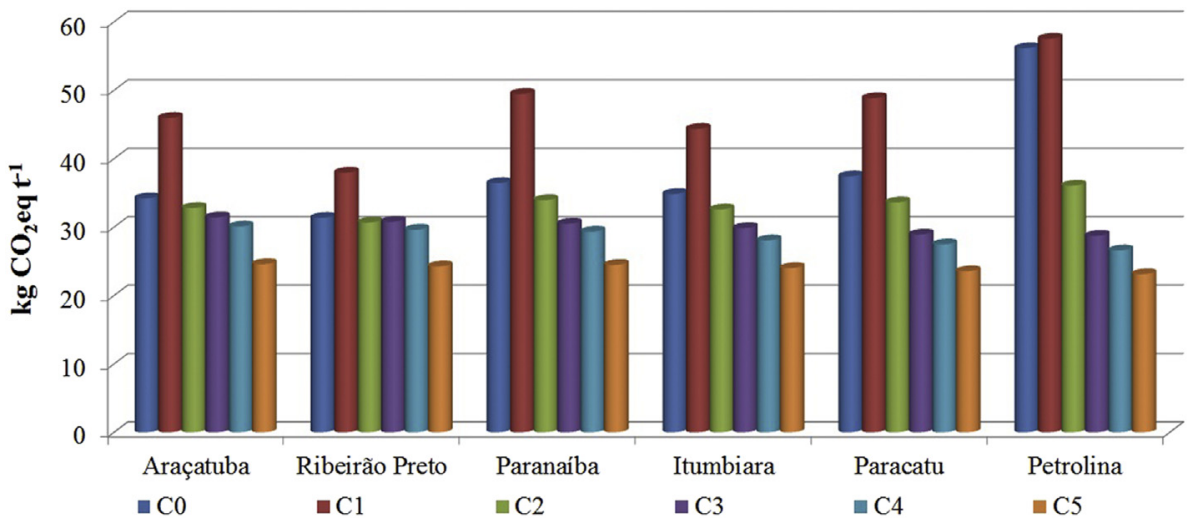

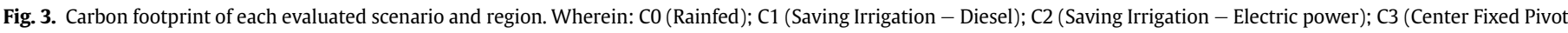
Irrigation); C4 (Drip Irrigation); C5 (Hypothetical Irrigation). 


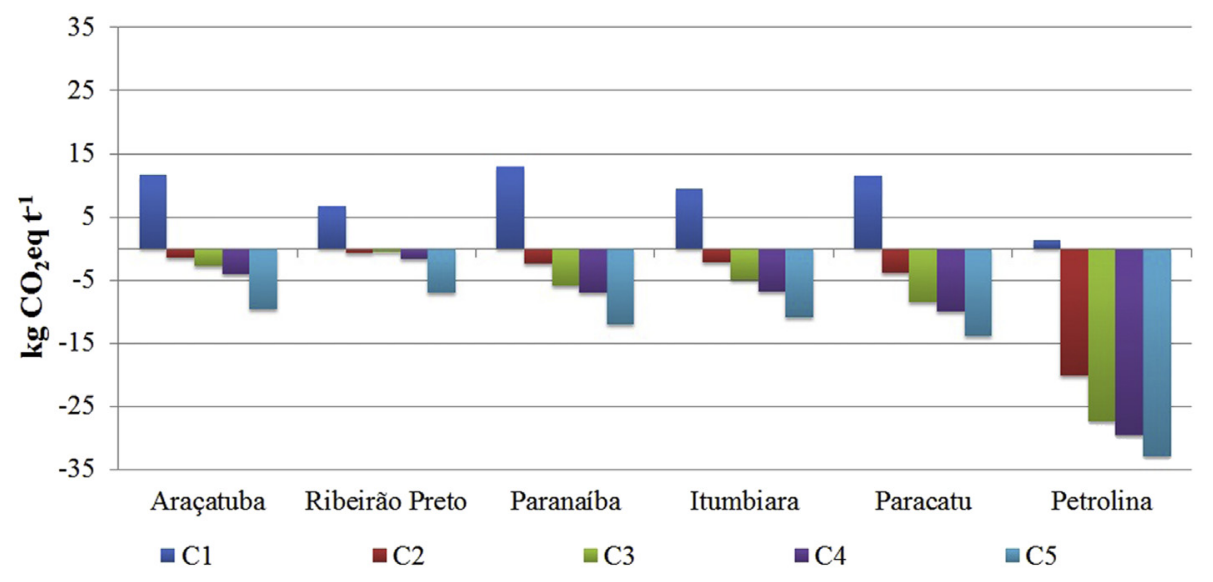

Fig. 4. Carbon footprint variation under diverse scenarios of irrigated sugarcane production ( $\mathrm{C} 1$ to $\mathrm{C} 5$ ) compared with rainfed condition (C0).

Scenarios under more intensive irrigation (C3, C4 and C5) had improved $\mathrm{C}$ footprint reductions. In $\mathrm{C} 3, \mathrm{C}$ footprint increased in the following order: Petrolina $\left(28.7 \mathrm{~kg} \mathrm{CO}_{2} \mathrm{eq} \mathrm{t}^{-1}\right)$, Paracatu (28.9 $\left.\mathrm{kg} \mathrm{CO}_{2} \mathrm{eq} \mathrm{t}^{-1}\right)$, Itumbiara (29.9 $\mathrm{kg} \mathrm{CO}_{2} \mathrm{eq} \mathrm{t} \mathrm{t}^{-1}$ ), Paranaíba (30.5 $\mathrm{kg} \mathrm{CO}_{2} \mathrm{eq} \mathrm{t}^{-1}$ ), Ribeirão Preto $\left(30.8 \mathrm{~kg} \mathrm{CO}_{2} \mathrm{eq} \mathrm{t}{ }^{-1}\right.$ ) and Araçatuba (31.4 $\mathrm{kg} \mathrm{CO}_{2} \mathrm{eq} \mathrm{t}^{-1}$ ). These irrigated scenarios had $\mathrm{C}$ footprint reductions compared to rainfed conditions in the following sequence: Petrolina (27.4 $\left.\mathrm{kg} \mathrm{CO}_{2} \mathrm{eq} \mathrm{t}^{-1}\right)$, Paracatu $\left(8.5 \mathrm{~kg} \mathrm{CO}_{2} \mathrm{eq} \mathrm{t}^{-1}\right)$, Paranaíba (5.9 kg CO $\mathrm{eq} \mathrm{t}^{-1}$ ), Itumbiara (5.0 $\mathrm{kg} \mathrm{CO}_{2} \mathrm{eq} \mathrm{t}^{-1}$ ), Araçatuba $\left(2.8 \mathrm{~kg} \mathrm{CO}_{2} \mathrm{eq} \mathrm{t}^{-1}\right)$ and Ribeirão Preto $\left(0.6 \mathrm{~kg} \mathrm{CO}_{2} \mathrm{eq} \mathrm{t}^{-1}\right)$.

In $\mathrm{C} 4, \mathrm{C}$ footprint values had the ascending order: Petrolina (26.6 $\mathrm{kg} \mathrm{CO}_{2} \mathrm{eq} \mathrm{t}^{-1}$ ), Paracatu (27.5 $\mathrm{kg} \mathrm{CO} \mathrm{CO}_{2} \mathrm{eq}^{-1}$ ), Itumbiara (28.1 kg CO $\left.2 \mathrm{eq} \mathrm{t}^{-1}\right)$, Paranaíba (29.3 $\left.\mathrm{kg} \mathrm{CO}_{2} \mathrm{eq} \mathrm{t}^{-1}\right)$, Ribeirão Preto (29.6 $\mathrm{kg} \mathrm{CO}_{2} \mathrm{eq} \mathrm{t}^{-1}$ ) and Araçatuba $\left(30.1 \mathrm{~kg} \mathrm{CO}_{2} \mathrm{eq} \mathrm{t} \mathrm{t}^{-1}\right)$. Contrasting with $\mathrm{C} 0, \mathrm{C} 4$ promoted $\mathrm{C}$ footprint reductions in the following order: Petrolina (29.6 kg CO $2 \mathrm{eq} \mathrm{t}{ }^{-1}$ ), Paracatu $\left(10.0 \mathrm{~kg} \mathrm{CO}_{2} \mathrm{eq} \mathrm{t}^{-1}\right)$ and Paranaíba $\left(7.1 \mathrm{~kg} \mathrm{CO}_{2} \mathrm{eq} \mathrm{t}^{-1}\right)$, followed by Itumbiara (6.8 $\left.\mathrm{kg} \mathrm{CO}_{2} \mathrm{eq} \mathrm{t}^{-1}\right)$, Araçatuba ( $4.1 \mathrm{~kg} \mathrm{CO}_{2} \mathrm{eq} \mathrm{t}^{-1}$ ) and Ribeirão Preto $\left(1.7 \mathrm{~kg} \mathrm{CO}_{2} \mathrm{eq} \mathrm{t}^{-1}\right)$.

Finally, C5 had the greatest reductions according to the ascending order: Petrolina $\left(23.1 \mathrm{~kg} \quad \mathrm{CO}_{2} \mathrm{eq} \mathrm{t}^{-1}\right)$, Paracatu (23.5 $\left.\mathrm{kg} \mathrm{CO}_{2} \mathrm{eq} \mathrm{t}^{-1}\right)$, Itumbiara $\left(24.0 \mathrm{~kg} \mathrm{CO}_{2} \mathrm{eq} \mathrm{t}^{-1}\right)$, Paranaíba $\left(24.5 \mathrm{~kg} \mathrm{CO}_{2} \mathrm{eq} \mathrm{t}^{-1}\right)$, Ribeirão Preto $\left(24.3 \mathrm{~kg} \mathrm{CO}_{2} \mathrm{eq} \mathrm{t}^{-1}\right)$ and Araçatuba $\left(24.6 \mathrm{~kg} \mathrm{CO}_{2} \mathrm{eq} \mathrm{t}^{-1}\right.$ ). In terms of variation, against $\mathrm{CO}$, this scenario reduced $\mathrm{C}$ footprint in the order: Petrolina (33.0 kg CO 2 eq t$~^{-1}$ ), Paracatu (13.9 kg CO eq $\left.\mathrm{t}^{-1}\right)$, Paranaíba $\left(12.0 \mathrm{~kg} \mathrm{CO}_{2} \mathrm{eq} \mathrm{t^{-1 }}\right)$, Itumbiara $\left(10.8 \mathrm{~kg} \mathrm{CO}_{2} \mathrm{eq} \mathrm{t} \mathrm{t}^{-1}\right)$, Araçatuba (9.6 $\mathrm{kg} \mathrm{CO}_{2} \mathrm{eq} \mathrm{t}^{-1}$ ) and Ribeirão Preto $\left(7.1 \mathrm{~kg} \mathrm{CO}_{2} \mathrm{eq} \mathrm{t}^{-1}\right.$ ).

\section{Discussion}

Assessing energy input in per hectare of sugarcane production in Iran, Sefeedpari et al. (2014) reported irrigation as the second largest energy consuming inputs, contributing for approximately $28 \%$ in total energy expenditures. Just like in Iran, promoting irrigation efficiency as well as employing modern irrigation technologies should be prioritized to attenuate GHG emissions in sugarcane irrigated areas in Brazil.

Regardless of the scenario, irrigation has led to significant increases of GHG emissions. Obviously, it was expected since this activity requires extra energy and inputs (Maraseni and Cockfield, 2012). Large diesel consumption in water pumps results in direct and indirect GHG emissions; consequently, scenarios, which are largely powered by diesel, would increase emissions per amount of applied water. According to Maraseni and Cockfield (2012), GHG emissions increase more than twice per kilogram of grain produced under irrigation (on average); these authors reported that irrigated chickpeas had emissions four times the levels in rainfed conditions. It is believed that rainfed agriculture generates lower emissions for every dollar generated by crops.

In contrast, we observed in this study some particularities of sugarcane production in Brazil, which substantially change this situation. First, Brazilian energy comes from relatively clean sources, such as hydropower and biomass burning of plants. Such sources reduce emissions considerably if compared to other fossil fuels. Thus, the spare amount of bagasse provided by crop irrigation would be used for cogeneration, supplying possible extra energy needs. Even though irrigated systems generate undeniable increase in total emissions, substantial gains in sugarcane yield and longevity can completely change circumstances in terms of GHG emission per ton of sugarcane produced (C footprint). Notwithstanding, the development of feasible strategies for combined water/energy savings is essential and indispensable to address a global challenge of using water resources efficiently and effectively (Bagatin et al., 2014).

Given the above mentioned, irrigation impact could not be assessed apart from evaluations of final production, energy source, grown crop and location. Different locations have particular climatic characteristics that may influence production under rainfed conditions as well as in irrigated scenarios. Furthermore, rainfall, air temperature, photoperiod, sunshine time, water storage capacity of soils are variables able to influence crop production and irrigation responses, besides of showing the economic and environmental feasibility of the system (Cardozo and Sentelhas, 2013). In Ribeirão Preto, for example, crop production has excellent performance under rainfed conditions because of rainfall regular distribution and increased water storage in soil (Cardozo, 2011). However, this region did not reach significant gains by applying irrigation as observed in other regions. The opposite situation is found in Petrolina, where low rainfall volumes make rainfed production unfeasible, as well as local technical-economic issues. Nevertheless, this region has some environmental features as high solar radiation availability (little cloudy sky) and high air temperature throughout the year (Table 1) enhance irrigation responses significantly in comparison with the other regions. Therefore, even in $\mathrm{C} 5$, in which power and input consumptions are increased (higher total emissions), C footprint was $48 \%$ lower than in Ribeirão Preto under rainfed conditions. The other regions are transitional areas between Ribeirão Preto and Petrolina, where water availability decreases with latitude; however, solar radiation and air temperature increase biomass production. 


\section{Conclusion}

As any other crop, sugarcane is extremely dependent on climatic conditions, which can be more or less beneficial to the plant development and biomass production. Irrigation can manage adverse conditions, enabling areas where rainfed is impracticable into large producing areas. However, irrigation intensifies and encumbers environmentally agricultural practices, since the practice promotes higher consumptions of electric power, diesel and other agricultural inputs, with emphasis on synthetic $\mathrm{N}$ fertilizers, which are one of the main contributors for GHG emissions. Overall, irrigation practice increased emissions in $245 \%$ compared to rainfed conditions. Nevertheless, it noteworthy to mention that the analyses should be carried out individually for each region, since local characteristics may significantly affect crop response and GHG emissions dynamics. The best example is Petrolina, where irrigation magnified crop yield and longevity, intensifying land use and delaying sugarcane field reform. Based on that, soil tillage and straw management, which contribute to GHG emissions, could be optimized for long-term storage of $C$ in the soil.

The increase in GHG emissions under irrigated conditions, however, should take into account the respective crop yield gains, as well as considering $C$ footprint, which is here described as environmental efficiency of the system. Initially, intensified agricultural activity increases GHG volume of emissions; however, irrigation promotes land use enhancement while reducing $C$ footprint. In addition, it may be one strategy to reduce agriculture impacts and negative externalities, enabling economic and social development of poor regions in the country.

Irrigation system characteristics are also important, since an efficient use of energy and water influences environmental and social impacts. Highly efficient irrigation systems, such as drip irrigation, enable production gains with less impact. As ethanol industry involves energy cogeneration, additional requirements are offset by an increased production. If "green" power sources are used under a proper management system, irrigation may generate a plus for the environment, since previously mentioned conditions and local requirements are ensured.

Eventually, our study has some constraints on the few number of studies approaching sugarcane irrigation, fertilization, soil management and GHG emissions. Therefore, there are variations about the contribution of some sources on GHG emissions. Furthermore, it is important to regard economic aspect of farming irrigation, which assures the sustainability of a system, as well as the environmental and technical features. In the light of this, further studies should appraise such aspects, thereby complementing the information presented herein.

\section{References}

AGO - Australian Greenhouse Office, 2006. Reducing GHG Emissions from Australian Agriculture: the Role of Benchmarking in Driving Best Management Practice. Australian Greenhouse Office, Canberra.

Bagatin, R., Klemeš, J.J., Reverberi, A.P., Huisingh, D., 2014. Conservation and improvements in water resource management: a global challenge. J. Clean. Prod. $77,1-9$.

Bordonal, R.O., De Figueiredo, E.B., La Scala, N., 2012. Greenhouse gas balance due to the conversion of sugarcane areas from burned to green harvest, considering other conservationist management practices. Glob. Change Biol. Bioenergy 4, $846-858$.

Camargo, A.P., Marin, F.R., Sentelhas, P.C., Giarolla, A., 1999. Ajuste da equação de thornthwaite para estimar a evapotranspiração potential em climas áridos e superúmidos, com base na amplitude térmica diária. Rev. Bras. Agrometeorol. 7, $251-257$.

Cardozo, N.P., 2011. Análise de risco econômico da cana-de-açúcar em função de condições climáticas de diferentes regiões do Estado de São Paulo. PECEGE/ ESALQ, Piracicaba, p. 66
Cardozo, N.P., 2013. Sustentabilidade técnica e ambiental da irrigação de cana-deaçúcar em diferentes regiões brasileiras. Escola Superior de Agricultura Luiz de Queiróz (ESALQ/USP), p. 105.

Cardozo, N.P., Sentelhas, P.C., 2013. Climatic effects on sugarcane ripening under the influence of cultivars and crop age. Sci. Agric. 70, 449-456.

Cardozo, N.P., Sentelhas, P.C., Panosso, A.R., Ferraudo, A.S., 2014. Multivariate analysis of the temporal variability of sugarcane ripening in south-eastern Brazil. Crop Pasture Sci. 65, 300-310.

Cerri, C.E.P., Sparovek, G., Bernoux, M., Easterling, W.E., Melillo, J.M., 2007. Tropical agriculture and global warming: impacts and mitigation options. Sci. Agric. 64 83-99.

Dalal, R.C., Wang, W.J., Robertson, G.P., Parton, W.J., 2003. Nitrous oxide emission from Australian agricultural lands and mitigation options: a review. Aust. J. Soil Res. 41, 165-195.

De Figueiredo, E.B., La Scala Jr., N., 2011. Greenhouse gas balance due to the conversion of sugarcane areas from burned to green harvest in Brazil. Agric. Ecosyst. Environ. 141, 77-85.

Demirbas, A., 2008. Biodiesel - a Realistic Fuel Alternative for Diesel Engines. Springer, London/UK, p. 208.

Doorenbos, J., Kassam, A.H., 1979. Yield Response to Water. FAO Irrigation and Drainage Paper No. 33. Food and Agriculture Organization (FAO), Rome, p. 139.

Endres, L., Silva, J.V., Ferreira, V.M., Barbosa, G.V.S., 2010. Photosynthesis and water relations in Brazilian sugarcane. Open Agric. J. 4, 31-37.

FNP, 2013. AGRIANUAL 2013: Yearbook of the Brazilian Agriculture. Consultoria e Agroinformativos, São Paulo (in Portuguese).

Freitas, R.G., Baffa, D.C.F., Brasil, R.P.C., 2009. Aumento na produtividade da cana-deaçúcar através da irrigação. Nucl. Edição Espec. 15-30.

Goldemberg, J., 2007. Ethanol for a sustainable energy future. Science 315, 808-810.

IPCC, 2006. Guidelines for national greenhouse gas inventories. In: Eggleston, S. Buendia, L., Miwa, K., Ngara, T., Tanabe, K. (Eds.), IPCC National Greenhouse Gas nventories Programme. Institute for Global Environmental Strategies (IGES), Hayama, Japan, p. 664.

IPCC, 2007. Climate change 2007: the physical science basis. In: Solomon, S., Qin, D. Manning M., Marquis, M., Averyt, K. Tignor, M.M.B., et al. (Eds.) Contribution of Working Group I to the Fourth Assessment Report of the Intergovernmental Panel on Climate Change. Cambridge University Press, Cambridge, United Kingdom and New York, NY, USA, p. 996.

Jank, M.S., 2010. Uma matriz de combustíveis para o Brasil. In: Sousa, E.L.L., Macedo, I.C. (Eds.), Ethanol e Bioeletricidade: a cana-de-açúcar no futuro da matriz energética, pp. 10-13. Available at: http://www.unica.com.br/download. php?idSecao=17\&id =43684046 (accessed 02.10.14.)

Linn, D.M., Doran, J.W., 1984. Effect of water-filled pore space on carbon dioxide and nitrous oxide production in tilled and no-tilled soils. Soil Sci. Soc. Am. J. 48 1267-1272.

Macedo, I.C., Leal, M.L.R.V., Silva, J.E.A.R., 2004. Balanço das emissões de gases de efeito estufa na produção e no uso do ethanol no Brasil. UNICA, São Paulo/SP. Available at: http://www.unica.com.br/download.php? idSecao $=17 \& \mathrm{id}=11168105$ (accessed 22.09.14.).

Macedo, I.C., Seabra, J.E.A., Silva, J.E.A.R., 2008. Green house gases emissions in the production and use of ethanol from sugarcane in Brazil: the 2005/2006 averages and a prediction for 2020. Biomass Bioenergy 32, 582-595.

Maraseni, T.N., Cockfield, G., 2012. Including the costs of water and greenhouse gas emissions in a reassessment of the profitability of irrigation. Agric. Water Manag. 103, 25-32.

Marouelli, W.A., Silva, H.R., 1998. Aspectos sanitários da água para fins de irrigação. EMBRAPA HORTALÍÇAS, Brasília, DF (in Portuguese).

MCT (Ministério da Ciência e Tecnologia), 2010. Fatores de Emissão de $\mathrm{CO}_{2}$ para utilizações que necessitam do fator médio de emissão do Sistema Interligado Nacional do Brasil, como, por exemplo. inventários corporativos. Available at: http://www.mct.gov.br/index.php/content/view/74694.html (accessed 13.12.14.).

MME (Ministério de Minas e Energia), 2015. Brazilian Energy review. PNE-Plano Nacional de Energia. Available at: http://www.mme.gov.br/documents/ 1138787/1732840/Resenha+Energ\%C3\%A9tica+-+Brasil+2015.pdf/4e6b9a346b2e-48fa-9ef8-dc7008470bf2 (accessed 13.08.15.) (in Portuguese).

Monteiro, L.A., Sentelhas, P.C., 2014. Potential and actual sugarcane yields in Southern Brazil as a function of climate conditions and crop management. Sugar Tech. 16 (3), 264-276.

Mosier, A.R. Delgado, J.A., Keller, M., 1998. Methane and nitrous oxide fluxes in an acid Oxisol in western Puerto Rico: effects of tillage, liming and fertilization. Soil Biol. Biochem. 30 (14), 2087-2098.

Nguyen, T.L.T., Gheewala, S.H., Sagisaka, M., 2010. Greenhouse gas savings potential of sugar cane bio-energy systems. J. Clean. Prod. 18, 412-418.

Oliveira, R.A., Santos, R.S., Ribeiro, A., Zolnier, S., Barbosa, M.H.P., 2012. Estimativa da produtividade da cana-de-açúcar para as principais regiões produtoras de Minas Gerais usando-se o método ZAE ${ }^{\mathrm{I}}$. Rev. Bras. Eng. Agric. Amb. 16 (5) 549-557.

Ronquim, C.C., 2007. Dinâmica espaço temporal do carbono aprisionado na fitomassa dos agroecossistemas do Nordeste do Estado de São Paulo. Documentos 63. Embrapa Monitoramento por Satélite, Campinas/SP, p. 52. Available at: http://www.cnpm.embrapa.br/publica/download/doc63_carbono_nesp.pdf (accessed 02.10.14.)

Scarpare, F.V., Leal, M.R.L.V., Victoria, R.L., 2015a. The challenges of sugarcane ethanol in Brazil: past, present and future. In: Dallemand, J.F., Hilbert, J.A., Monforti, F. (Eds.), The Challenges of Sugarcane Ethanol in Brazil: Past, Present 
and Future, first ed. Publications Office of the European Union, Luxembourg, pp. 91-104.

Scarpare, F.V., Hernandes, T.A.D., Ruiz-Corrêa, S.T., Kolln, O.T., Gava, G.J.C., Dos Santos, L.N.S., Victoria, R.L., 2015b. Sugarcane water footprint under different management practices in Brazil: Tietê/Jacaré watershed assessment. J. Clean. Prod. 1-9 http://dx.doi.org/10.1016/j.jclepro.2015.05.107.

Sefeedpari, P., Shokoohi, Z., Behzadifar, Y., 2014. Energy use and carbon dioxide emission analysis in sugarcane farms: a survey on Haft-Tappeh Sugarcane AgroIndustrial Company in Iran. J. Clean. Prod. 83, 212-219.

Smith, P., Martino, D., Cai, Z., Gwary, D., Janzen, H., 2007. Policy and technological constraints to implementation of greenhouse gas mitigation options in agriculture. Agric. Ecosyst. Environ. 118, 6-28.

Spironello, A., van Raij, B., Penatti, C.P., et al., 1997. Cana-de-açúcar. In: van Raij, B., Cantarella, H., Quaggio, J.A., Furlanio, A.M.C. (Eds.), Recomendações de adubação e calagem para o Estado de São Paulo. Instituto Agronômico de Campinas (IAC), Campinas, SP, Brasil, pp. 237-239.
Tammisola, J., 2010. Towards much more efficient biofuel crops - can sugarcane pave the way? GM Crops 1 (4), 181-198.

Thornthwaite, C.W., Mather, J.R., 1955. The water balance. In: Drexel Institute of Climatology, Publications in Climatology VIII. Drexel Institute of Climatology, New Jersey, p. 104

Thornthwaite, C.W., 1948. An approach toward a rational classification of climate. Geogr. Rev. 38 (1), 55-94.

Trivellin, P.C.O., Vitti, A.C., 2005. Manejo do nitrogênio e enxofre na nutrição e adubação da cana-de-açúcar. In: Simpósio de tecnologia de produção de cana-deaçúcar, Anais. IPNI (International Plant Nutrition Institute), Piracicaba, SP, p. 46.

Vianna, M.S., Sentelhas, P.C., 2015. Performance of DSSAT CSM-CANEGRO under operational conditions and its use in determining the 'Saving irrigation' impact on sugarcane crop. Sugar Tech. 1-12.

Vergé, X.P.C., De Kimpe, C., Desjardins, R.L., 2007. Agricultural production, greenhouse gas emissions and mitigation potential. Agric. For. Meteorol. 142 255-269. 